\title{
Optical coherence tomography in an optic tract lesion
}

\author{
Retinal nerve fiber layer changes
}

Figure 1 Spectral-domain OCT reveals a bow-tie atrophy pattern in the right eye and predominant superior and inferior nerve fiber layer loss in the left eye
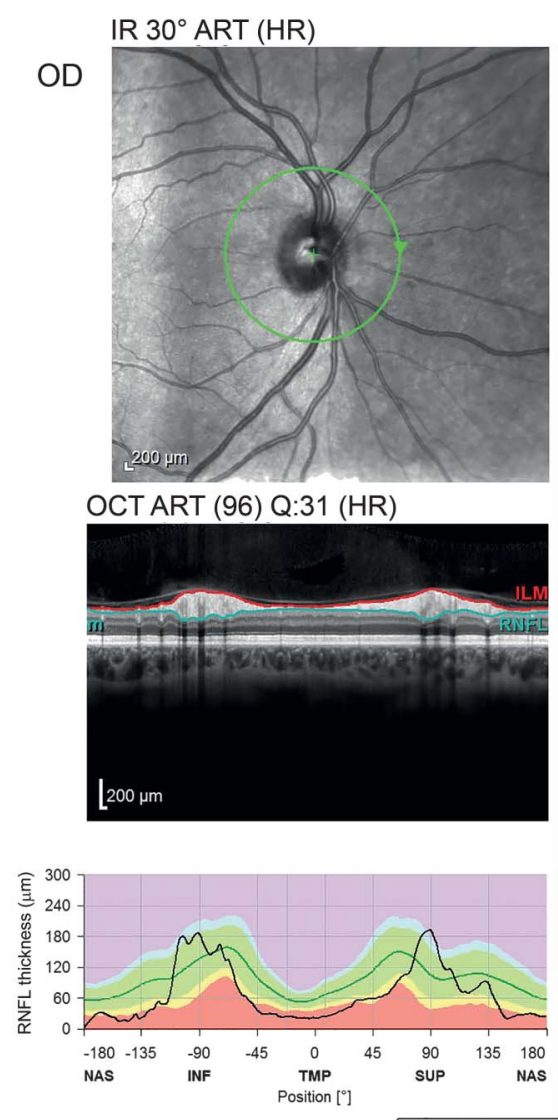

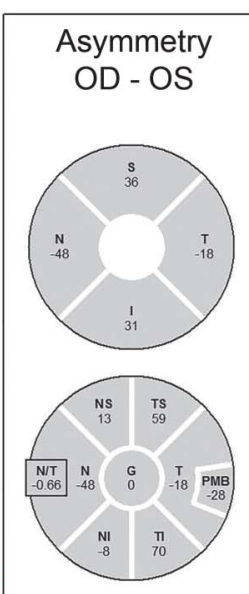

IR $30^{\circ}$ ART (HR)

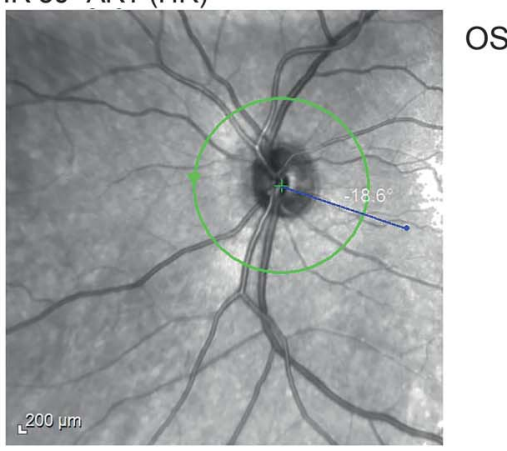

OCT ART (96) Q:30 (HR)

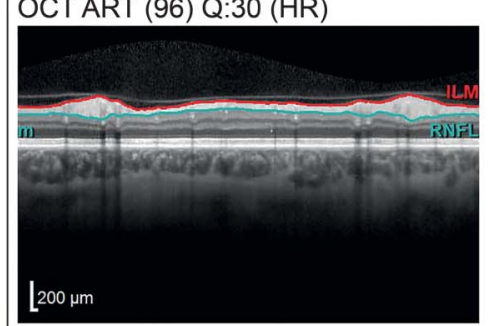
$\underset{(p<0.01)}{\operatorname{Above} \text { normal limits }}$

Borderline above $(p<0.05)$

Within normal limits $(p>0.05)$

Borderline below $(p<0.05)$

Below normal limits $(p<0.01)$

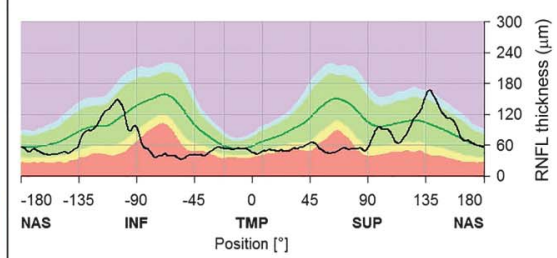

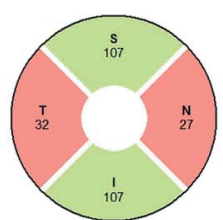
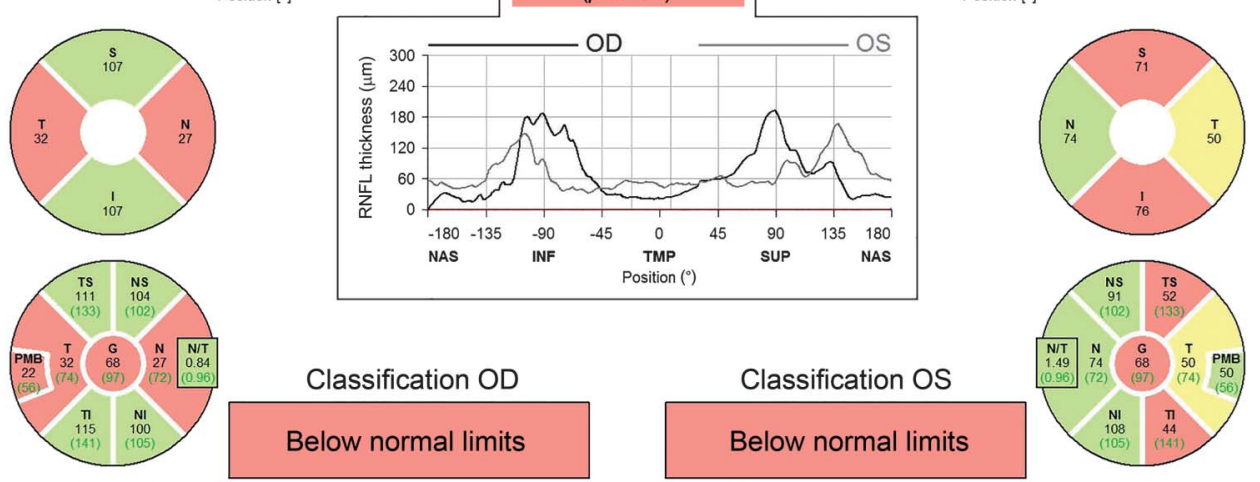

Warning: Classification results valid for Caucasian eyes only

Classification OS

Below normal limits
Supplemental data at Neurology.org
$\mathrm{OCT}$ = optical coherence tomography; OD = oculus dexter (right eye); OS = oculus sinister (left eye); RNFL = retinal nerve fiber layer.

A 49-year-old woman, status post temporal lobe resection, reported a hemianopia. Examination revealed a right afferent pupillary defect, horizontal bow-tie atrophy OD (temporal and nasal), and temporal atrophy OS. Optical coherence tomography showed a bow-tie pattern OD and predominant superior and inferior nerve 


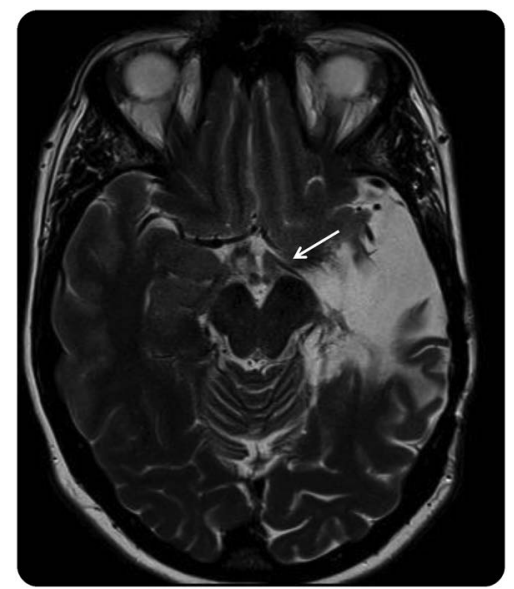

Atrophy of the left optic tract (arrow) and encephalomalacia of adjacent temporal lobe are seen.

fiber layer loss OS (figure 1; figure e-1 at Neurology.org). The pattern OD is due to the combination of papillomacular bundle and nasal RNFL loss. The pattern OS is due to nerve fiber layer loss temporal to the fovea and, coupled with papillomacular bundle loss, produces temporal pallor. ${ }^{1}$ MRI confirmed left optic tract atrophy (figure 2). Optical coherence tomography may be sensitive for detecting localizing atrophic patterns. ${ }^{2}$

Alexandra J. Lloyd-Smith, MD, MSc, Kannan Narayana, MD, Floyd Warren, MD, Laura J. Balcer, MD, MSCE, Steven L. Galetta, MD, Janet C. Rucker, MD

From the Departments of Neurology (A.J.L.-S., K.N., F.W., L.J.B., S.L.G., J.C.R.), Population Health (L.J.B.), and Ophthalmology (F.W., L.J.B., S.L.G.), New York University School of Medicine, NY.

Author contributions: Study concept and design: A.J.L.-S., K.N., S.L.G., J.C.R. Acquisition of data: A.J.L.-S., K.N., F.W., J.C.R. Analysis and interpretation: A.J.L.-S., K.N., F.W., J.C.R., S.L.G. Critical revision of the manuscript for important intellectual content: L.J.B., S.L.G., J.C.R. Study supervision: L.J.B., S.L.G., J.C.R.

Study funding: No targeted funding reported.

Disclosure: The authors report no disclosures relevant to the manuscript. Go to Neurology.org for full disclosures.

Correspondence to Dr. Rucker: Janet.rucker@nyumc.org

1. Newman SA, Miller NR. Optic tract syndrome: neuro-ophthalmologic considerations. Arch Ophthalmol 1983;101:1241-1250.

2. Goto K, Miki A, Yamashita T, et al. Sectoral analysis of the retinal nerve fiber layer thinning and its association with visual field loss in homonymous hemianopia caused by post-geniculate lesions using spectral-domain optical coherence tomography. Graefes Arch Clin Exp Ophthalmol 2016;254:745-756.

\section{WriteClick ${ }^{\circledR}$ rapid online correspondence}

Have a comment on a recent Neurology ${ }^{\circledR}$ article you would like to share? Now it is easier and more convenient. Neurology.org has launched WriteClick on the home page and sidebars of each article to encourage remarks and debate among users.

WriteClick is restricted to comments about studies published in Neurology within the last eight weeks.

Learn more at Neurology.org/letters 


\section{Neurology}

\section{Optical coherence tomography in an optic tract lesion: Retinal nerve fiber layer changes}

Alexandra J. Lloyd-Smith, Kannan Narayana, Floyd Warren, et al.

Neurology 2016;87;2063-2064

DOI 10.1212/WNL.0000000000003310

This information is current as of November 7, 2016

\section{Updated Information \&} Services

References

Subspecialty Collections

Permissions \& Licensing

Reprints including high resolution figures, can be found at: http://n.neurology.org/content/87/19/2063.full

This article cites 2 articles, 0 of which you can access for free at: http://n.neurology.org/content/87/19/2063.full\#ref-list-1

This article, along with others on similar topics, appears in the following collection(s):

All Clinical Neurology

http://n.neurology.org/cgi/collection/all_clinical_neurology All Education

http://n.neurology.org/cgi/collection/all_education

All Neuro-ophthalmology

http://n.neurology.org/cgi/collection/all_neuroophthalmology

MRI

http://n.neurology.org/cgi/collection/mri

Information about reproducing this article in parts (figures,tables) or in its entirety can be found online at:

http://www.neurology.org/about/about_the_journal\#permissions

Information about ordering reprints can be found online:

http://n.neurology.org/subscribers/advertise

Neurology ${ }^{\circledR}$ is the official journal of the American Academy of Neurology. Published continuously since 1951, it is now a weekly with 48 issues per year. Copyright @ 2016 American Academy of Neurology. All rights reserved. Print ISSN: 0028-3878. Online ISSN: 1526-632X.

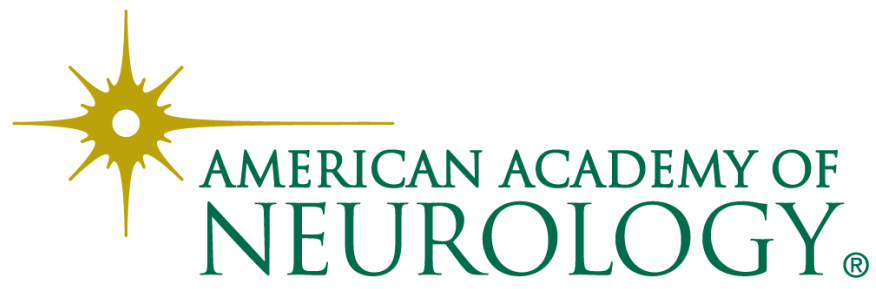

